Anete Trajman 1,2 Márcia Teresa Belo 1,2 Eleny G. Teixeira 1,2 Vicente C. S. Dantas 1 Frederico M. Salomão 1,2 Antônio J. Ledo A. Cunha 3

\section{Knowledge about STD/AIDS and sexual behavior among high school students in Rio de Janeiro, Brazil}

\author{
Conhecimento sobre DST/AIDS \\ e comportamento sexual entre estudantes \\ do ensino médio no Rio de Janeiro, Brasil
}

1 Departamento de Clínica Médica, Fundação

Técnico-Educacional Souza Marques. Rua do Catete 6, Rio de Janeiro, $R J$ 22220-000, Brasil. atrajman@centroin.com.br 2 Departamento de Medicina, Universidade Gama Filho. Rua Manoel Vitorino 553 Prédio AG, 4o andar, Rio de Janeiro, $R J$ 20748-900, Brasil.

3 Departamento de Pediatria, Universidade Federal do Rio de Janeiro. Av. Brigadeiro Trompowsky $s / n o$, Rio de Janeiro, $R J$ 21942-590, Brasil.

\begin{abstract}
The incidence of AIDS and other sexually transmitted diseases (STDS) is increasing among adolescents. In order to better understand high-risk sexual behavior among students, a cross-sectional study based on a self-answered anonymous questionnaire was conducted in 10 public and private high schools in Rio de Janeiro, Brazil. Data were obtained on sociodemographics, knowledge of STD/AIDS, and sexual behavior. Among 945 students aged 13-21, 59\% were sexually initiated, and the median age at first sexual intercourse was 15 years (range: 7-19). Although 94\% reported being aware of the need for condom use for protection, only 34\% informed always using condoms during sex. Low family income was associated with unsatisfactory knowledge $(O R=9.40 ; 95 \% C I=6.05-14.60)$ and inconsistent condom use $(O R=11.60 ; 95 \%$ $C I=5.54-24.30$ ). However, unsatisfactory knowledge was not associated with inconsistent condom use. School-based educational programs should focus on sexual behavior more than on transmission of knowledge, as well as targeting low-income students.
\end{abstract}

Key words Acquired Immunodeficiency Syndrome; Sexually Transmitted Diseases; Sex Behavior; Adolescence

Resumo A incidência da AIDS e outras doenças sexualmente transmissíveis (DST) vem aumentando entre adolescentes. Com o objetivo de melhor conhecer o comportamento sexual de risco entre estudantes do ensino médio, foi realizado um estudo transversal baseado em um questionário anônimo e auto-aplicado em dez escolas do Rio de Janeiro. Obtivemos dados sócio-demográficos e informações sobre o conhecimento de DST/AIDS e sobre o comportamento sexual. Entre os 945 estudantes de 13 a 21 anos, 59\% já haviam iniciado a sua vida sexual. A mediana de idade da primeira relação sexual foi de 15 anos (amplitude 7-19). Embora 94\% conhecessem a proteção conferida pelo uso do preservativo, somente $34 \%$ declararam usá-lo sempre. Houve associação entre baixa renda familiar e conhecimento insatisfatório $(O R=9,40 ;$ IC95\% $=6,05$ $14,60)$ e do uso inconstante de preservativos $(O R=11,60 ;$ IC95\% $=5,54-24,30)$. Não houve entretanto associação entre conhecimento insatisfatório e uso inconstante de preservativo. Programas educacionais devem focalizar o comportamento mais do que a transmissão da informação $e$ priorizar jovens de baixa renda familiar.

Palavras-chave Síndrome de Imunodeficiência Adquirida; Doenças Sexualmente Transmissiveis; Comportamento Sexual; Adolescência 


\section{Introduction}

The annual incidence of AIDS and other sexually transmitted diseases (STDs) is increasing among adolescents throughout the world. It is estimated that 15,000 new HIV infections/day occurred in 1999 worldwide, $50 \%$ of which in individuals under the age of $24 ; 13,000$ were in the 15 to 49 year-old range (UNAIDS, 2000a).

In Brazil, half a million adults were estimated to be infected with HIV in 2000. During the year 2000 and until March 2001, 13,932 new AIDS cases were reported, with a total of 210,447 accumulated cases since the beginning of the epidemic. The city of Rio de Janeiro has the second highest absolute number of cases (MS, 2000 ). The $15-24$ age group represents $13 \%$ of all reported AIDS cases, corresponding to 20,064 individuals (MS, 2000). One of the major changes in the epidemic has involved female adolescents. While in 1997 the male:female ratio was 23:1 among adolescents, it had decreased to only 2:1 by 1999 (Santos \& Santos, 1999).

It has been suggested that knowledge about STD transmission might influence sexual behavior among adolescents (Agrawal et al., 1999; $\mathrm{Ku}$ at al., 1998; Lahai-Momoh \& Ross, 1997). In Brazil, the Ministry of Health has promoted wide media campaigns recommending condom use, yet the epidemic has progressed despite these campaigns. In order to obtain data to guide future educational strategies, we conducted a questionnaire survey among high school students in Rio de Janeiro. Their knowledge about STD/AIDS and their sexual behavior were assessed, and associations with sociodemographic characteristics were analyzed.

\section{Methods}

This was a cross-sectional study with students from 10 high schools in the city of Rio de Janeiro, Brazil. The city has 5.6 million inhabitants and 609 high schools, 401 of which are private. According to the 1991 census, out of 488,274 inhabitants aged 15 to $19,127,161$ (26\%) were enrolled in high schools (IBGE, 1997). We arbitrarily limited the study to 10 schools based on our capacity to visit them and collect data during the study period. The 10 schools were selected from different districts of Rio de Janeiro (south, north, and west zones) and included religious and secular, private and public schools. All high school students attending class on the day of the survey were eligible to participate.

Data on the students' knowledge about STDs, sexual behavior, preferred and most com- monly used source of information about STDs, and sociodemographic characteristics (age, gender, family income, public/private school attendance) were collected using 22 questions.

Based on the responses given to the questions that evaluated knowledge, we created a new variable using the median score of correct answers to only 9 questions, selected according to their discriminating ability: those which were correctly answered by more than $95 \%$ of the respondents were disregarded. Using factor analysis, principal components approach, and those 9 questions, we generated a score. Each student was then classified using this score, and the distribution of scores was produced. Students who scored above the 50th percentile in this distribution were classified as having "satisfactory" knowledge; otherwise they were classified as having "unsatisfactory" knowledge.

Questions to assess risk behavior included condom use (inconsistent use was defined as those who denied always using condoms during sex); age at first sexual intercourse, history of intercourse with professional sex workers, and number of partners in the previous 12 months.

Family income was assessed according to criteria from the Brazilian Institute of Public Opinion and Statistics (IBOPE). Briefly, the number of household appliances (including television, freezer, refrigerator, washing machine) and head of family's schooling were used. We used an arbitrary U\$ 420/month cut-off to define "low family income" (IBOPE, 2001).

Data were collected during December 1999 using an anonymous self-answered questionnaire. Two authors (V. C. S. D. and F. M. S.) visited schools, and before classes began students were asked to answer the questionnaire after providing informed consent. Questionnaires were answered and returned immediately in order to avoid identification: students left them on a table, one on top of the other, with the answers facing down.

The association between unsatisfactory knowledge as an outcome variable and the following independent variables was examined: male gender, older age ( $>15$ years), low family income (under U\$420/month), public school attendance, absence of dialogue with parents about STD/AIDS, and lack of classes on STD/ AIDS at school.

The association between inconsistent condom use as an outcome variable and the same above-mentioned independent variables was also examined. We also included unsatisfactory knowledge as an independent variable in this latter analysis. 
After a descriptive analysis, a bivariate analysis was conducted to assess the presence of associations between outcome and independent variables (results not shown). The variables significantly associated with the outcome variables (unsatisfactory knowledge and inconsistent condom use) in the bivariate analysis were subsequently studied in a multivariate analysis using logistic regression models. For each outcome variable a separate model was created to assess the effect of each independent variable. No interaction variable was tested, because we did not have a prior hypothesis to support interaction. The Hosmer-Lemeshow test was used to assess goodness-of-fit for all models. The adjusted odds ratio (OR) was used as the measure of association. Student's t-test was used to compare means; the chi-squared test was used to compare proportions, and confidence intervals were determined for point estimates. Level of significance was set at 0.05 . Analysis was performed using Stata software version 4.0 (Stata Corporation, 1995).

Principals from all the participating schools gave permission for the study. Volunteers only participated after informed consent. The protocol was approved by the ethics committee of the Mercy Hospital (Santa Casa da Misericórdia), Rio de Janeiro.

\section{Results}

The questionnaire was answered by 945 high school students from 4 private and 6 public schools located in different neighborhoods, including the west (Campo Grande), north (Ilha do Governador), and south zones (Santa Teresa, Laranjeiras) of the city. The survey was conducted prior to both daytime and evening classroom shifts, when available. The number of students in each school was as follows: 222 , $142,72,73,38,100,111,72,59$, and 56. Their sociodemographic characteristics are displayed in Table 1. There was no difference between male and female median age $(p=0.30)$. Among students in private schools, $97 \%$ had a high family income, contrasting with $57 \%$ in public schools $(\mathrm{p}<0.0001)$.

All students had heard about AIDS, 89\% about gonorrhea, $65 \%$ about syphilis, and $63 \%$ about genital herpes. One hundred percent, $81 \%, 58 \%$, and $60 \%$ of the students were aware of the sexual transmission route of those four diseases, respectively. The proportions of correct answers to questions concerning HIV transmission are presented in Table 2. The following independent variables were associated with

\begin{tabular}{|c|c|}
\hline \multicolumn{2}{|c|}{$\begin{array}{l}\text { Sociodemographic characteristics of } 945 \text { high school } \\
\text { students. Rio de Janeiro, Brazil, } 1999 .\end{array}$} \\
\hline \multicolumn{2}{|l|}{ Characteristics } \\
\hline Median age (range) & $16(13-21)$ years \\
\hline Female & $17(14-21)$ years \\
\hline Male & $16(13-20)$ years \\
\hline \multicolumn{2}{|l|}{ Gender } \\
\hline Female & $502(53 \%)$ \\
\hline Male & 443 (47\%) \\
\hline \multicolumn{2}{|l|}{ School } \\
\hline Private & $510(54 \%)$ \\
\hline Public & $435(46 \%)$ \\
\hline \multicolumn{2}{|l|}{ Family income } \\
\hline$\geq \cup \$ 1,870$ & $301(32 \%)$ \\
\hline U\$ 800-U\$ 1,869 & $211(22 \%)$ \\
\hline U\$ 420-U\$ 799 & $155(16 \%)$ \\
\hline U\$ 220-U\$ 419 & $215(23 \%)$ \\
\hline$<$ U\$ 220 & $63(7 \%)$ \\
\hline
\end{tabular}

Table 2

Percentage of affirmative answers in a questionnaire on HIV sexual transmission and condom use among 945 high school students. Rio de Janeiro, Brazil, 1999.

\begin{tabular}{lc}
\hline Questions & $\%$ \\
\hline HIV can be transmitted... & 93 \\
Man-to-man & 99 \\
Woman-to-man & 91 \\
Man-to-woman & \\
HIV can be transmitted through.... & 98 \\
Vaginal sex & 69 \\
Oral sex & 90 \\
Anal sex & 94 \\
Condom use protects against HIV transmission & 94 \\
Each condom may be used only once & 72 \\
AIDS may be transmitted even if you only have sex \\
with your boy/girlfriend
\end{tabular}


unsatisfactory knowledge according to multivariate analysis: low family income, lack of classes on STD/AIDS at school, and absence of dialogue on STD/AIDS with parents, as shown in Table 3.

Among the 945 students, $59 \%$ were sexually initiated, and the median age at first sexual intercourse was 15 years (range 7-19). Reported sexual behavior among sexually initiated students is summarized in Table 4. Sixty-four percent had their first sexual intercourse before their sixteenth birthday. Males started sexual experience earlier than females $(14 \pm 2.2$ years versus $15.2 \pm 1.5$ years, $\mathrm{p}<0.0001)$. Among sexually initiated boys, 15 (5\%) had their first intercourse before their eleventh birthday, contrasting with none of the sexually initiated girls.

Only $34 \%$ of the students reported always using condoms. Variables independently associated with inconsistent condom use in the multivariate analysis were low family income, lack of classes on STD/AIDS in school, and older age ( $>15$ years), as shown in Table 5 .

Among 388 students (41\%) who reported never having had sexual intercourse, $79 \%$ reported that they intended to use condoms in the future.

Males reported more sexual partners in the past 12 months $(3.2 \pm 3.8$ versus $1.9 \pm 1.7, \mathrm{p}<0.01)$.

Among 303 sexually initiated boys, 176 (58\%) declared having had intercourse at least once with a professional sex worker, $19 \%$ of whom without using condoms, contrasting with 4 out of $254(2 \%, p<0.0001)$ of sexually initiated girls.

Television was the most frequent source of information (97\%) on STD/AIDS. Thirty percent reported having no dialogue about either about sex or AIDS with their parents; $90 \%$ felt that their level of knowledge was insufficient, and $78 \%$ would prefer to have more information through conferences/classes in school.

\section{Discussion}

High-risk sexual behavior among adolescents is a major concern to parents, educational professionals, and health authorities throughout the world. Previous studies have demonstrated that gender and social class are strong determinants of high-risk sexual behavior (DuRant et al., 1992; Sonenstein et al., 1991; Warren et al., 1998). However, there is controversy as to whether knowledge can influence sexual behavior (Agrawal et al., 1999; DiClemente, 1992; $\mathrm{Ku}$ et al., 1998; Theill et al., 1993; UNAIDS, 2000a). In our study in Rio de Janeiro, a large metropolitan city where AIDS incidence among adolescents has increased in recent years (MS, 2000), all students reported knowing that AIDS is sexually transmitted and that condom use reduces risk of transmission. They also demonstrated satisfactory overall knowledge of AIDS. However, many misconceptions were detected. Awareness that transmission can occur through oral sex by an apparently healthy person and by a boyfriend or girlfriend was often lacking, and $16 \%$ thought AIDS was a curable disease. In addition, young students in our study reported having frequently engaged in high-risk sexual behaviors. Although 94\% reported knowing that condoms protect against HIV transmission, only $34 \%$ reported always using condoms. The same was found in previous studies in Brazil (Antunes et al., 1997; Fernandes, 1998; Pinto et al., 1994). In contrast, most adolescents who reported not having initiated sexual activity declared their intent to use condoms in the future. Recent Brazilian data have shown that condom use during first sexual intercourse increased from $4 \%$ in 1986 to $48 \%$ in 1999 (UNAIDS, 2000b). Despite this impressive increase, the proportion of condom use is still unacceptably low.

Other high-risk behaviors were also observed in our study, including multiple part-

Table 3

Independent variables associated with unsatisfactory knowledge in the multivariate analysis*

High school students from Rio de Janeiro, Brazil, 1999.

\begin{tabular}{lccc}
\hline Independent variables & OR & 95\% Cl & P value \\
\hline Low family income & 9.4 & $6.0-14.6$ & $<0.001$ \\
Lack of classes on STD/AIDS in school & 2.0 & $1.5-2.7$ & $<0.001$ \\
Absence of dialogue on STD/AIDS with parents & 1.8 & $1.2-2.5$ & $<0.001$ \\
\hline
\end{tabular}

* Final model included all three variables, gender, and age. 
ners (defined as $>2$ in 12 months, CDC, 1999), early sexual debut, and intercourse with professional sex workers, sometimes without condoms. Previous studies in the United States (DuRant et al., 1992; Sonenstein et al., 1991; Warren et al., 1998) have suggested that highrisk sexual behavior is statistically associated with non-White color. However, such findings may reflect the social class of non-White individuals in the United States. We observed that low family income was closely associated with unsatisfactory knowledge and with inconsistent condom use. In our study, gender was not significantly associated with inconsistent condom use. In other reports, girls reported safer behavior (Dekin, 1996; Langille et al., 1998), starting their sexual activity at a later age, and engaging with fewer partners.

In the present study, students reported surprisingly young sexual debut, which contrasts with recent reports from adults (BEMFAM/ Macro International, 1997). However, our study only included students under 21 years of age, which limited the age of sexual debut. In other words, in the future the currently non-sexually initiated students ( $41 \%$ of the sample) will tend to increase the median age of the total sample at first intercourse.

Interestingly, attending classes on STD/AIDS at school, but not unsatisfactory knowledge, was associated with condom use. It is difficult to explain how classes at school can be associated with safer behavior if not through knowledge. However, it is possible that the use of interactive teaching strategies may change adolescents' self-perception of risk and vulnerability. In fact, most students reported self-perception of insufficient knowledge and expressed the need for further formal sex education. Dialogue with parents about STD/AIDS was also associated with better knowledge. These findings highlight the importance of information and open debate both at home and in school about STDs and sexual practices.

Our study has important limitations that deserve mentioning. The sample included only part of the high schools in the city. Our findings can thus not be generalized to all high school students from Rio de Janeiro. In addition, $74 \%$ of the 15-19-year-old population in Rio de Janeiro are not enrolled in high schools (IBGE, 1997). This includes homeless, working, and junior high school adolescents. Although $30 \%$ of the participating students had a monthly family income of less than U\$ 420, the data cannot be generalized to the excluded population of highly vulnerable adolescents not attending high school (Fernandes, 1998; Pinto et

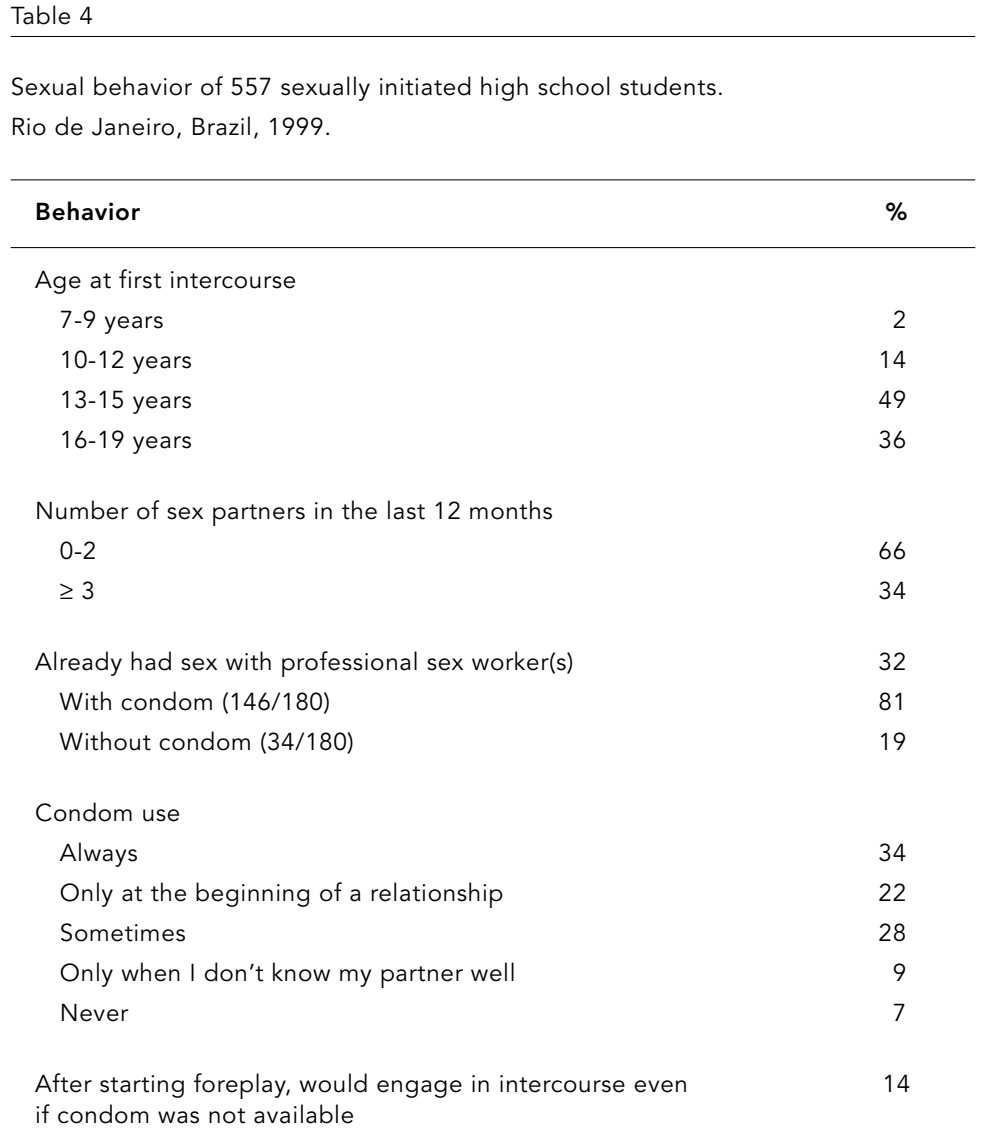

Table 5

Independent variables associated with inconsistent condom use in the multivariate analysis*. High school students from Rio de Janeiro, Brazil, 1999.

\begin{tabular}{lrcr}
\hline Independent variables & OR & $\mathbf{9 5 \% ~ C l}$ & p value \\
\hline Low family income & 11.6 & $5.54-24.3$ & $<0.001$ \\
Older age (> 15 years) & 5.6 & $2.4-12.0$ & $<0.001$ \\
Lack of classes on STD/AIDS at school & 2.4 & $1.54-3.71$ & $<0.001$
\end{tabular}

* Final model included all three variables, unsatisfactory knowledge, and absence of dialogue with parents.

al., 1994). A clustering strategy for selection of the sample was not used. Instead, a convenience sample based on consent by the school principals was used. However, we included schools with different curricular approaches and located in different areas of the city, thus ensuring a wide range of students. In addition, other possible confounding factors were not included in the models. Finally, limitations associated with the use of self-answered ques- 
tionnaires need to be considered, such as the difficulties in validating answers, mainly since anonymity could not be fully guaranteed. However, we believe that our study provides relevant information for a better understanding of knowledge and sexual behavior among high school students in Rio de Janeiro.

In summary, although high school students in Rio de Janeiro reported satisfactory knowledge of HIV transmission, they also reported having frequently engaged in high-risk sexual behavior, including early sexual debut, multi- ple sex partners, and inconsistent condom use. The high school curriculum, mainly in public schools, should consider including formal sex education. School-based HIV-prevention programs should go beyond the simple transfer of information. Our results suggest that sex education programs to encourage safe sex practices should target low-income adolescents. However, alternative strategies should be defined for adolescents living in the streets and other underprivileged population groups.

\section{References}

AGRAWAL, H. K.; RAO, R. S.; CHANDRASHEKAR, S. \& COULTER, J. B., 1999. Knowledge of and attitudes to HIV/AIDS of senior secondary school pupils and trainee teachers in Udupi district, Karnatak, India. Annals of Tropical Paediatrics, 19:143-149.

ANTUNES, M. C.; STALL, R. D.; PAIVA, V.; PERES, C. A.; PAUL, J.; HUDES, M. \& HEARST, N., 1997. Evaluating an AIDS sexual risk reduction program for young adults in public night schools in São Paulo, Brazil. AIDS, 11(Sup. 1):S121-127.

BEMFAM (Sociedade Civil Bem-Estar Familiar no Brasil) / MACRO INTERNATIONAL, 1997. Brasil Pesquisa Nacional sobre Demografia e Saúde, 1996. Rio de Janeiro: BEMFAM/Macro International.

CDC (Centers for Disease Control and Prevention), 1999. Trends in HIV-related sexual risk-behaviors among high school students - Selected U.S. cities, 1991-1997. MMWR, 48:440-443. 
DEKIN, B., 1996. Gender differences in HIV-related self-reported knowledge, attitudes, and behaviors among college students. American Journal of Preventive Medicine, 12(Sup. 1):61-66.

DiCLEMENTE, R. J.; DURBIN, M.; SIEGEL, D.; KRASNOVSKY, F.; LAZARUS, N. \& COMACHO, T., 1992. Determinants of condom use among junior high school students in a minority, inner-city school district. Pediatrics, 89:197-202.

DuRANT, R. H.; ASWORTH, C. S.; NEWRNAN, C. \& GAILLARD, G., 1992. High school students' knowledge of HIV/AIDS and perceived risk of currently having AIDS. Journal of School Health, 62:59-63.

FERNANDES, J. C., 1998. Trends in HIV/AIDS-related knowledge, attitudes, and practices in a Rio de Janeiro slum population. Cadernos de Saúde Pública, 14:575-581.

IBGE (Fundação Instituto Brasileiro de Geografia e Estatística), 1997. Contagem da População 1966. v. I. Rio de Janeiro: IBGE.

IBOPE (Instituto Brasileiro de Opinião Pública e Estatística), 2001. Critério Brasil Mede o Poder Aquisitivo do Consumidor. 19 Agosto $2001<\mathrm{http}$ /// www.ibope.com.br/social/aspprc20.htm>.

KU, L.; SONENSTEIN, F. L.; LINDBERG, L. D.; BRADNER, C. H.; BOGGESS, S. \& PLECK, J. H., 1998. Understanding changes in sexual activity among young metropolitan men: 1979-1995. International Family Planning Perspectives and Digest, 30:256-262.

LAHAI-MOMOH, J. C. \& ROSS, M. W., 1997. HIV/AIDS prevention-related social skills and knowledge among adolescents in Sierra Leone, West Africa. African Journal of Reproduction Health, 1:37-44.

LANGILLE, D. B.; ANDREOU, P.; BEAZLEY, R. P. \& DELANEY, M. E., 1998. Sexual health knowledge of students at a high school in Nova Scotia. Canadian Journal of Public Health, 89:85-89.
MS (Ministério da Saúde), 2000. Boletim Epidemiológico. Ano XIII, no. 1, Semana Epidemiológica 48/99 a 22/00. Dezembro de 1999 a Junho de 2000, Tabela IV, p. 29 <http://www.aids.gov.br/udtv/ boletim_dez99_jun00/tabela_4.htm>.

PINTO, J. A.; RUFF, A. J.; PAIVA, J. V.; ANTUNES, C. M.; ADAMS, I. K.; HALSEY, N. A. \& GRECO, D. B., 1994. HIV risk behavior and medical status of underprivileged youths in Belo Horizonte, Brazil. Journal of Adolescent Health, 15:179-185.

SANTOS, V. L. \& SANTOS, C. E., 1999. Adolescentes, jovens e AIDS no Brasil. In: Cadernos Juventude, Saúde e Desenvolvimento (N. Schor, M. S. F. Tabosa-Mota \& V. Castelo-Branco, org.), v. 1, pp. 213222, Brasília: Área de Saúde do Adolescente e do Jovem, Secretaria de Políticas de Saúde, Ministério da Saúde.

SONENSTEIN, F. L.; PLECK, J. H. \& KU, L. C., 1991. Levels of sexual activity among adolescent males in the United States. International Family Planning Perspectives and Digest, 23:162-167.

THEILL, O.; HOVELER, S.; TANGERMANN, R. \&WAHN, V., 1993. Adolescents and AIDS: Sex behavior, knowledge, and attitudes. Results of a survey of students in a large West German city. Monatsschrift fur Kinderheilkunde, 141:421-426.

UNAIDS, 2000a. Global AIDS Epidemic Update and Country Reports. June $2000<$ http://www.unaids.org/ epidemic_update/report/epi_core/sld007.htm>.

UNAIDS, 2000b. Report on the Global HIVIAIDS Epidemic. Geneva: UNAIDS.

WARREN, C. W.; SANTELLI, J. S.; EVERETT, S. A.; KANN, L.; COLLINS, J. L.; CASSELL, C.; MORRIS, L. \& KOLBE, L. J., 1998. Sexual behavior among U.S. high school students, 1990-1995. International Family Planning Perspectives and Digest, 30: 170-172.

Submitted on 14 November 2001

Final version resubmitted on 3 April 2002

Approved on 12 July 2002 